\title{
Evaluación de la efectividad del cloruro de magnesio hexahidratado (Bischofita) como estabilizador químico de capas de rodadura granulares
}

\author{
Evaluation of hexahydrated magnesium chloride (Bischofite) \\ performance as a chemical stabilizer of \\ granular road surfaces
}

GUILLERMO THENOUX Z.,SERGIO VERA A. Departamento de Ingeniería y Gestión de la Construcción, Escuela de Ingeniería, Pontificia Universidad Católica de Chile

CHILE

Fecha de recepción:: 15-I-01

Fecha de aceptación: 4-V-01

\section{RESUMEN}

El Cloruro de Magnesio Hexahidratado o Bischofita es una sal. Ésta posee diversas propiedades que permiten su uso potencial como estabilizador químico de capas de rodadura granulares: capacidad de absorber y retener la humedad del ambiente circundante, incrementa la tensión superficial del agua y reduce la presión de vapor del agua. La investigación tuvo el propósito de evaluar la efectividad de la Bischofita como estabilizador químico de caminos no pavimentados, y se basa en resultados de ensayos de laboratorio y la evaluación de tramos de prueba de capas de rodadura estabilizadas con Bischofita en zonas áridas y semi-áridas de Chile. En general, los resultados de terreno han sido más significativos que los de laboratorio, observándose que la adición de Bischofita permite obtener una capa de rodadura estable, reduce la formación de baches, corrugaciones, pérdida de áridos y emisiones de polvo, y mejora la calidad de rodadura.

\section{SUMMARY}

Hexahydrated Magnesium Chloride or Bischofite is a salt. It has different properties that enable it to be useful as a chemical stabilizer of granular road surfaces: its capacity of absorbing and retaining humidity from its surrounding environment, increases water surface tension and decreases its vapor pressure. The objective of this research was to evaluate Bischofite performance as a chemical stabilizer of granular road surfaces. Research was based on laboratory tests and the evaluation of test road sections of granular road surfaces stabilized with Bischofite in arid and semi-arid zones of Chile. In general, the field trial results have been more conclusive than the laboratory tests. The use of Bischofite creates a stable granular road surface, reduces potholes, corrugations, erosion and dust emissions, and improves the riding quality.
PALABRAS CLAVE: capas rodadura, estabilización, suelos Bischofita

\section{INTRODUCCIÓN}

En Chile, al igual que en la mayoría de los países en desarrollo, los caminos no pavimentados son el principal componente de la red vial, y están conformados por capas de rodadura de tierra o grava.
KEYWORDS: road surfaces, stabilization, soils Bischofite

\section{INTRODUCTION}

In Chile, as in most developing countries, unpaved roads, composed of gravel or earth, are the principle component of the road network. These roads are fundamental to the economic and social development 
Estos caminos son fundamentales para el desarrollo económico y social de tales países, ya que facilitan el acceso a zonas urbanas y rurales, y a centros de explotación de la industria forestal, minera y agrícola.

Como consecuencia de las solicitaciones de tránsito y climáticas, junto a la falta de recursos para implementar programas de conservación adecuados, los caminos no pavimentados suelen deteriorarse rápidamente, generando diversos problemas, tales como: 1) Continuos requerimientos de conservación. 2) Contaminación de plantas y fuentes de agua debido a emisiones de polvo. 3) Dificultad para la integración social. 4) Deterioro de bienes públicos y privados. 5) Incremento de los costos de operación de los vehículos. 6) Disminución de la seguridad vial.

Para reducir el elevado costo social y económico asociado a los problemas generados por los caminos no pavimentados, es necesario implementar políticas que permitan mejorar gradualmente el estándar de estos caminos, siendo la estabilización química una opción factible técnica y económicamente en muchos países del mundo.

La Bischofita ha sido evaluada en diversos países como supresor temporal de polvo, técnica que consiste en aplicar un riego de salmuera (Bischofita más agua) sobre la superficie del camino, obteniéndose muy buenos resultados $(1,2)$. En cambio, la utilización de Bischofita como estabilizador químico (mezcla íntegra del suelo con Bischofita en todo el espesor de la capa de rodadura) no ha sido evaluada.

El objetivo principal de esta investigación fue evaluar técnicamente la efectividad de la Bischofita como estabilizador químico de capas de rodadura granulares, en términos de su efecto sobre las propiedades físicas y mecánicas de los suelos, reducción del deterioro superficial y durabilidad de caminos estabilizados con Bischofita.

\section{ASPECTOS DE LA ESTABILIZACION DE SUELOS CON BISCHOFITA}

\subsection{Propiedades de la Bischofita}

La Bischofita es una sal cuya fórmula química es $\mathrm{MgCl}_{2} \cdot 6 \mathrm{H}_{2} \mathrm{O}$. En cloruro de magnesio puro $\left(\mathrm{MgCl}_{2}\right) \mathrm{o}$ en cristales de Bischofita está disponible a nivel mundial. La Tabla 1 muestra el análisis químico típico de la Bischofita producida en Chile, la cual tiene bajos contenidos de impurezas. of these countries, as they facilitate access to urban and rural zones, as well as forestry, mining and agricultural production centers.

Due to traffic and climatic demands, combined with the lack of resources to carry out adequate maintenance programs, unpaved roads deteriorate quickly, causing various problems; such as: 1) Continuous maintenance requirements. 2) Contamination of plants and water sources due to dust emissions. 3) Difficulty for social integration. 4) Deterioration of public and private facilities. 5) Increments in vehicle operation costs. 6) Decrease in road safety.

In order to reduce the elevated social and economic costs associated with the problems generated by unpaved roads, it is necessary to implement policies which permit a gradual improvement of the condition of these roads, chemical soil stabilization being a technically and economically feasible option.

Bischofite has been evaluated in different countries as a dust suppressant, a technique which consists in the application of a Bischofite brine spray (Bischofite plus water) directly to the road surface. Excellent results have been achieved with this type of applications $(1,2)$. On the other hand, the use of Bischofite as a granular road surface stabilizer (Bischofite and granular material mixed in all surface course thickness) has not been evaluated.

The main objective of this research was to technically evaluate Bischofite's performance as a chemical stabilizer of granular road surfaces, in terms of its effect on the physical and mechanical properties of soils, the reduction of road surface deterioration and the durability of roads stabilized with Bischofite.

\section{ASPECTS OF SOIL STABILIZATION WITH BISCHOFITE}

\subsection{Bischofite properties}

Bischofite is a salt whose chemical formula is $\mathrm{MgCl} \cdot 6 \mathrm{H}_{2} \mathrm{O}$. Pure magnesium chloride $\left(\mathrm{MgCl}_{2}\right)$ or magnesium chloride crystals (Bischofite) are available worldwide. Table 1 shows the typical chemical analysis of Bischofite produced in Chile, which has low contents of impurities. 
TABLA 1/TABLE 1

Análisis químico típico de la Bischofita

(Typical chemical analysis of Bischofite)

\begin{tabular}{|c|c|}
\hline $\begin{array}{c}\text { Químico } \\
\text { Chemical }\end{array}$ & $\begin{array}{c}\text { Porcentaje } \\
\text { Percentage }\end{array}$ \\
\hline $\mathrm{Mg}$ & 10,5 \\
\hline $\mathrm{Cl}$ & 33,5 \\
\hline $\mathrm{H}_{2} \mathrm{O}$ & 52,0 \\
\hline $\mathrm{K}, \mathrm{Li}, \mathrm{SO}_{4}, \mathrm{Na}, \mathrm{B}$ & 4,0 (máx.) \\
\hline
\end{tabular}

El "compuesto activo" de la Bischofita es el cloruro de magnesio, el cual tiene diversas propiedades fisicas que permiten su uso potencial como estabilizador químico de caminos no pavimentados, siendo las principales (3):

\section{Delicuescencia}

Es la capacidad de absorber la humedad del aire y disolverse en esta humedad para formar una solución líquida. El cloruro de magnesio absorbe agua cuando la humedad relativa es superior al $32 \%$, proceso que cesa cuando la presión de vapor de la solución salina originada es igual a la presión de vapor de la atmósfera. Además, el cloruro de magnesio tiene la capacidad de retener la humedad absorbida por un tiempo prolongado, el cual depende de las condiciones climáticas prevalecientes. La cantidad de agua absorbida es proporcional a la superficie expuesta de la sal, a la humedad relativa del aire y a la concentración de $\mathrm{MgCl}_{2}$ en solución.

Presión de vapor

La presión de vapor de soluciones de cloruro de magnesio es significativamente menor que la del agua a cualquier temperatura y humedad relativa, reduciendo la tasa de evaporación del agua hasta 3,1 veces.

Incremento de la tensión superficial del agua

Como se aprecia en la Figura 1, la adición de cloruro de magnesio al agua permite incrementar la tensión superficial de ésta hasta un $45 \%$, lo cual reduce la tasa de evaporación del agua.

Temperatura de congelamiento

La temperatura de congelamiento de soluciones salinas es significativamente menor a la del agua
The "active component" of Bischofite is magnesium chloride, which has physical properties that permit its potential use as a chemical stabilizer on unpaved roads. Its main properties are (3):

\section{Deliquescence}

It is the capacity to absorb moisture from the air and of dissolving in this humidity to form a liquid solution. Magnesium chloride absorbs moisture when the relative humidity is above $32 \%$, a process which continues to act until an equilibrium is reached between the vapor pressure of the saline solution and that of the surrounding air. Magnesium chloride also has the capacity of retaining the absorbed moisture for an extended period of time, a characteristic which depends upon the prevalent climatic conditions. The quantity of water absorbed is proportional to the exposed surface of the salt, the air's relative humidity and the concentration of $\mathrm{MgCl}_{2}$ in the solution.

\section{Vapor pressure}

The vapor pressure of magnesium chloride is significantly less than that of water at any temperature and relative humidity. $\mathrm{MgCl}_{2}$ reduces the water evaporation rate up to 3.1 times.

\section{Increase of water surface tension}

As noted in Figure 1, the addition of magnesium chloride to water allows a water surface tension increase of up to $45 \%$, which in turn reduces water evaporation.

\section{Freezing point}

The freezing point of saline solutions is much lower than that of water. It is one of the most well-known 


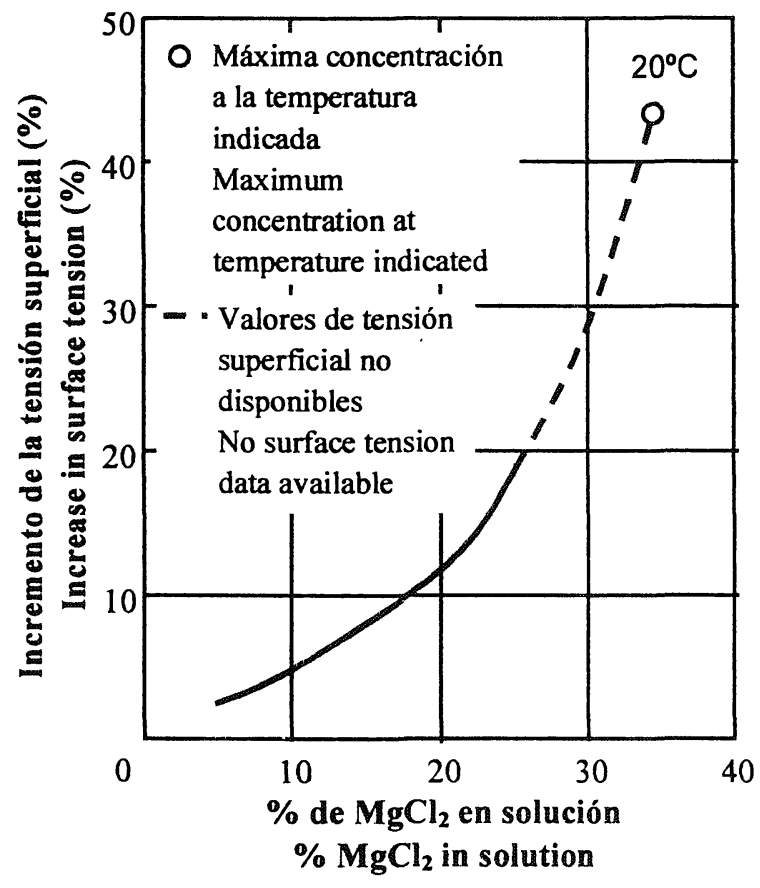

Figura 1.- Incremento de la tensión superficial.

Figure 1.- Increase in surface tension.

pura. Esta es una de las propiedades más reconocidas de las sales, siendo por ello ampliamente utilizadas en calles y carreteras para derretir la nieve y el hielo acumulado en la superficie de la calzada.

La Figura 2 muestra el diagrama de fase del cloruro de magnesio. La temperatura eutéctica es cercana a $-32{ }^{\circ} \mathrm{C}$ para una concentración de $22 \%$ de $\mathrm{MgCl}_{2}$.

\subsection{Mecanismo de estabilización}

De acuerdo a lo indicado por Kézdi (3), el mecanismo de estabilización de la Bischofita consiste en:

Absorción y retención de humedad en la superficie de rodadura

La superficie de rodadura de un camino estabilizado con Bischofita absorbe el agua del aire durante las horas de mayor humedad relativa (principalmente durante la noche y en la mañana). Esta humedad es retenida durante un período de tiempo que depende de las condiciones climáticas. Así, se evita la pérdida de partículas finas en forma de polvo y la posterior pérdida de partículas más gruesas.

Cristalización de la Bischofita en la superficie de rodado

Bajo condiciones de baja humedad relativa, generalmente en la tarde en climas áridos, se produce la cristalización del cloruro de magnesio en la fracción superior de la

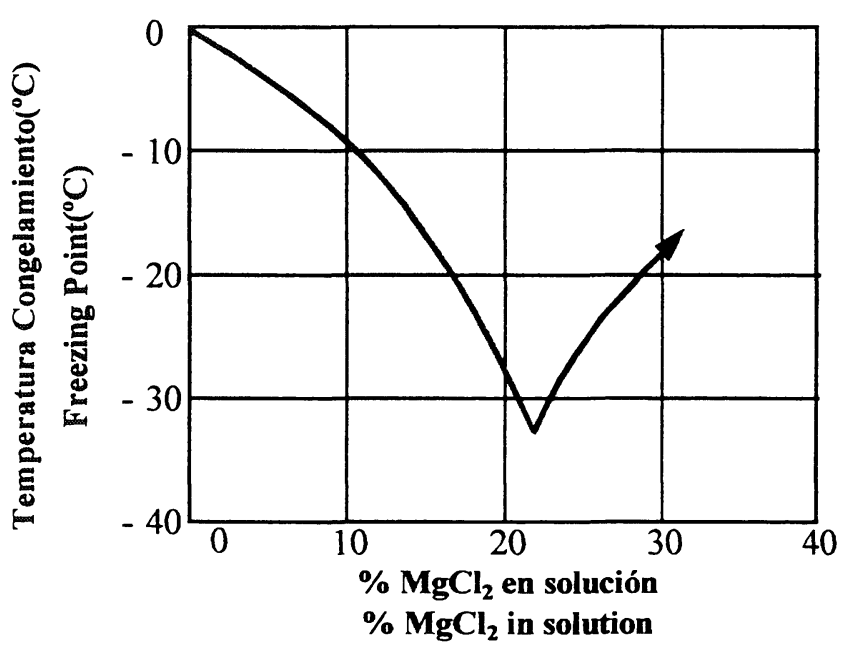

Figura 2.- Diagrama de fase del $\mathrm{MgCl}_{2}$. Figure 2.- Freezing point of $\mathrm{MgCl}_{z}$

properties of all salts, therefore, salts are widely used on roads and highways as a de-icer.

Figure 2 shows the freezing point of magnesium chloride. The Eutectic temperature is closer to $-32{ }^{\circ} \mathrm{C}$ with a $22 \%$ content of $\mathrm{MgCl}_{2}$ in the solution.

\subsection{Stabilization mechanism}

According to Kézdi (3), the stabilization mechanism of Bischofite consists of:

Absorption and retention of humidity by the road surface

Road surfaces stabilized with Bischofite absorb humidity from the air during the hours of greater relative humidity (principally during the night and early morning). Such moisture is retained during a period of time that depends upon climatic conditions. This reduces the loss of fine particles (such as dust) and erosion.

Crystallization of Bischofite on the road surface

Under conditions of low relative humidity, generally in the evening in arid climates, magnesium chloride crystallizes in the upper fraction of road surfaces, 
superficie de rodado, cementando las partículas finas. Esto forma una costra dura que resiste la acción abrasiva del tránsito, $\mathrm{y}$, como consecuencia, se reduce la tasa de deterioro y mejora la calidad de rodadura.

\section{Aglomeración de partículas finas}

La adición de Bischofita al suelo permite la aglomeración de las partículas finas, mecanismo que difiere si se trata de suelos no plásticos o de alta plasticidad. En suelos no plásticos y de baja plasticidad, tales como limos y arenas finas, el mecanismo de aglomeración es consecuencia de la mayor tensión superficial de la solución salina que rodea las partículas. La película de agua que rodea las partículas finas de suelo es como un "puente elástico" que une partículas adyacentes, al agregar Bischofita al suelo mejora la resistencia de este puente elástico, ayudando a mantener unidas las partículas e incrementando la resistencia al corte.

En suelos de alta plasticidad con un alto contenido de arcillas, la adición de Bischofita produce la aglomeración de los minerales de arcilla debido al intercambio de iones. El intercambio de iones reduce la carga negativa del mineral de arcilla, y, por ende, el espesor de la película de agua adsorbida y la repulsión entre las partículas. La menor repulsión, junto a una mayor tensión superficial de la solución salina, tiene como consecuencia que las fuerzas de atracción (del tipo Van der Waals) entre las partículas se incremente relativamente, causando su aglomeración (4).

\section{Estabilidad frente ciclos de hielo/deshielo}

Debido a que el cloruro de magnesio reduce el punto de congelamiento del agua del suelo, permite minimizar el daño de la capa de rodadura granular causado por los ciclos de hielo / deshielo.

\section{METODOLOGÍA DE ESTUDIO, PRESENTACIÓN Y ANÁLISIS DE RESULTADOS}

La investigación fue divida en dos partes: laboratorio y terreno.

\subsection{Investigación en laboratorio}

Esta parte de la investigación consistió en la realización de diferentes ensayos de laboratorio para evaluar el efecto de distintas dosis de Bischofita sobre ciertas propiedades físicas y mecánicas de los suelos, lo cual se realizó comparando los resultados cementing the fine particles. This forms a hard crust that resists the abrasive action of traffic, and as a consequence reduces the deterioration rate and improves the riding quality.

\section{Flocculation of fine particles}

The addition of Bischofite to the soil permits the flocculation of the fine particles, a mechanism that differs in non-plastic or high plasticity soils. In non-plastic and low plasticity soils, such as limes and fine sands, the flocculation mechanism is a consequence of the greater surface tension of the saline solution surrounding the particles. The water film that surrounds the fine particles of soils is like an "elastic bridge" that joins adjacent particles. Adding Bischofite to the soils improves the resistance of this elastic bridge, helping to join the fine particles and increasing shear stress resistance.

In soils of high plasticity with high clay content, the addition of Bischofite produces the flocculation of clay minerals due to ion exchanges. The ion exchange reduces the negative charge on the clay particles. This helps to reduce the repulsion between clay particles as well as the thickness of their insulating water film. The reduced repulsion coupled with a greater surface tension of the saline solution results in an increase of the attractive forces (Van der Waals forces) between clay particles, causing its flocculation (4).

\section{Frost protection}

Magnesium chloride depresses the freezing point of water in soil, which helps to minimize frost heave in granular road surfaces.

\section{STUDY METHODOLOGY, PRESENTATION AND ANALYSIS OF RESULTS}

The investigation was divided into laboratory and field investigation.

\subsection{Laboratory study}

Laboratory tests were performed to evaluate the effects of different Bischofite contents on physical and mechanical soil properties. This was achieved comparing the results obtained from non-treated and 
obtenidos entre suelos tratados y no tratados con Bischofita. Los ensayos realizados fueron: 1) Límites de Atterberg. 2) Compactación. 3) Resistencia a la compresión no confinada. 4) Retención de humedad.

La Bischofita fue aplicada al suelo en forma de salmuera, y los contenidos de Bischofita utilizados en los ensayos fueron 3, 5 y $7 \%$ del peso del suelo seco.

\section{Límites de Atterberg}

Se ensayaron dos suelos, cuyo índice de plasticidad corresponde a 6 y 11 respectivamente. En general, no se apreciaron cambios significativos del límite líquido, límite plástico e índice de plasticidad debido a la adición de Bischofita. Estos resultados coinciden con los encontrados por Singh y Das (5) en un estudio de estabilización de suelos realizado con cloruro de sodio. La causa de estos resultados es que la cantidad de arcilla y su plasticidad no son suficientes para que se produzca el intercambio de iones.

\section{Compactación}

La Tabla 2 muestra los suelos utilizados para evaluar el efecto de la Bischofita sobre la relación humedaddensidad. Los resultados del ensayo de compactación modificado son presentados en la Figura 3. Como se aprecia, en todos los suelos hay un incremento de la densidad máxima compactada seca (D. M. C. S.) cuando son mezclados con Bischofita, dependiendo del suelo y de la dosis de Bischofita, la magnitud del incremento varía entre 0,8 y $5,4 \%$ con respecto a la densidad del suelo no tratado.

La Bischofita afecta también el contenido de humedad óptima del suelo. La Figura 3 muestra una significativa reducción del contenido óptimo de humedad en suelos con Bischofita.

El incremento de la densidad y la reducción del contenido óptimo de humedad son atribuidos al efecto lubricador de la solución salina, como consecuencia de la mayor tensión superficial de la solución de Bischofita.

\section{Resistencia a la compresión no confinada (CNC)}

El propósito de este ensayo fue evaluar indirectamente y en forma relativa el efecto de distintos contenidos de Bischofita sobre la capacidad de soporte del suelo. Cómo la Bischofita actúa básicamente sobre la fracción fina de los suelos, sólo se utilizaron suelos bajo el tamiz ASTM N ${ }^{\circ}$ 4. En la Tabla 3 se indican las principales características de los suelos ensayados.

Se prepararon probetas de suelo sin Bischofita, y con dosis de 3, 5 y $7 \%$ de Bischofita. Para un mismo suelo, treated soils. The laboratory tests performed were: 1$)$ Atterberg Limits. 2) Compaction. 3) Unconfined Compression Strength. 4) Humidity Retention.

Bischofite contents of $3 \%, 5 \%$ and $7 \%$ (dry soil weight) were applied as brine.

\section{Atterberg Limits test}

Two soils were tested, with plasticity indices of 6 and 11 respectively. In general, the addition of Bischofite has no influence on the liquid limit, plastic limit or plasticity index. These results coincide with those found by Sing and Das (5) in a study of soil stabilization with sodium chloride. These results are due to the fact that the quantity of clay and its plasticity are not sufficient to produce the ion exchanges.

\section{Compaction test.}

Table 2 shows the soil properties utilized to evaluate the effect of Bischofite on the compaction properties of soils. The results of the compaction test are shown in Figure 3. It can be seen that the dry unit weight (D. U. W.) increases when the soils are mixed with Bischofite. Depending on soil type and Bischofite content, the increment varies between $0.8 \%$ and $5.4 \%$ compared to the soil's D. U. W. without Bischofite.

Bischofite also affects the optimum moisture content of soils. Figure 3 shows a significant reduction of moisture content in soils with Bischofite.

The increase of the D.U.W. and the reduction of moisture content are attributed to the saline solution's lubrication effect, as a consequence of the greater surface tension of the Bischofite solution.

\section{Unconfined compression (UC) strength test}

The purpose of this test was to evaluate indirectly and comparatively the effect of different Bischofite contents upon the soil capacity support. Since Bischofite acts principally on the soil's fine particle fraction, only soils under ASTM sieve $N^{\circ} 4$ were used. Table 3 shows the main soil property results.

The specimens were prepared with 0, 3, 5 and $7 \%$ Bischofite contents. For the same soil, specimens were 
TABLA 2/TABLE 2

Propiedades de los suelos para el ensayo de compactación

(Soil properties for compaction test)

\begin{tabular}{|c|c|c|c|c|c|}
\hline $\begin{array}{c}\text { Tamiz } \\
\text { Sieve size }\end{array}$ & \multicolumn{5}{|c|}{$\begin{array}{l}\text { Porcentaje que pasa } \\
\text { Percent passing }\end{array}$} \\
\hline ASTM & $\begin{array}{c}\text { Suelo 1 } \\
\text { Soil } 1\end{array}$ & $\begin{array}{c}\text { Suelo } 2 \\
\text { Soil } 2\end{array}$ & $\begin{array}{l}\text { Suelo } 3 \\
\text { Soil } 3\end{array}$ & \begin{tabular}{|c|} 
Suelo 4 \\
Soil 4
\end{tabular} & $\begin{array}{c}\text { Suelo } 5 \\
\text { Soil } 5\end{array}$ \\
\hline 3" & & 100 & & & \\
\hline $21 / 2^{n}$ & & 96 & & & 100 \\
\hline $2 "$ & 100 & 95 & & 100 & 93 \\
\hline $11 / 2^{n}$ & 98 & 94 & & 98 & 90 \\
\hline 1" & 96 & 92 & 100 & 82 & 85 \\
\hline 3/4" & 93 & 89 & 99 & 74 & 83 \\
\hline $3 / 8^{\prime \prime}$ & 86 & 83 & 96 & 56 & 75 \\
\hline $\mathrm{N}^{\circ} 4$ & 78 & 75 & 92 & 46 & 69 \\
\hline$N^{\circ} 10$ & 69 & 66 & 84 & 35 & 59 \\
\hline $\mathrm{N}^{\circ} 40$ & +7 & 47 & 48 & 21 & 33 \\
\hline N200 & 28 & 24 & 16 & 9 & 13 \\
\hline $\begin{array}{l}\text { Límite Líquido (\%) } \\
\text { Liquid Limit (\%) }\end{array}$ & 24 & 19 & - & 27 & - \\
\hline $\begin{array}{l}\text { Límite Plistico (\%) } \\
\text { Plastic Limit (\%) }\end{array}$ & 12 & 15 & - & 14 & - \\
\hline $\begin{array}{l}\text { Indice de Plasticidad } \\
\text { Plasticity Index }\end{array}$ & 12 & 4 & NP & 13 & NP \\
\hline \multicolumn{6}{|c|}{ Clasificación/Classification } \\
\hline AASHTO & A-2-6 & $A-1-b$ & $A-1-b$ & A-2-6 & $A-1-b$ \\
\hline USCS & $\mathrm{SC}$ & SM - SC & SM & $G W-G C$ & SM \\
\hline
\end{tabular}

las probetas fueron preparadas con el mismo contenido de humedad y al $93 \%$ de la D.M.C.S. del suelo sin Bischofita, esto con el propósito de minimizar el efecto de estas variables sobre la resistencia a la $\mathrm{CNC}$ del suelo.

Las probetas fueron ensayadas después de un período de curado a 0,7 y 14 días en una cámara climatizada a una temperatura de $20 \pm 1,0^{\circ} \mathrm{C}$ y humedad relativa de $26 \pm 6 \%$. La Figura 4 muestra las curvas de tendencia de resistencia para distintos contenidos de Bischofita de probetas a 14 días de curado. En éstas se aprecia que en todos los suelos se produce un incremento de la resistencia para un cierto contenido de Bischofita. Como se observa no hay una relación clara entre la magnitud del incremento de la resistencia y las propiedades del suelo. prepared with the same moisture content and $93 \%$ of the soil's D.U.W without Bischofite. The objective was to minimize the effect of these variables on the soil's unconfined compression strength.

Specimens were tested after 0,7 and 14 days of curing in a climatic chamber at $20\left( \pm 1{ }^{\circ} \mathrm{C}\right)$ and a relative humidity of $26( \pm 6 \%)$. Figure 4 shows the tendency curves of specimens' UC strength after a 14 day curing period. These results present a UC strength increase in all soils. This increment is not proportional to the Bischofite content. It can be observed that there is no clear relationship between the magnitude of strength increase and soil properties. 

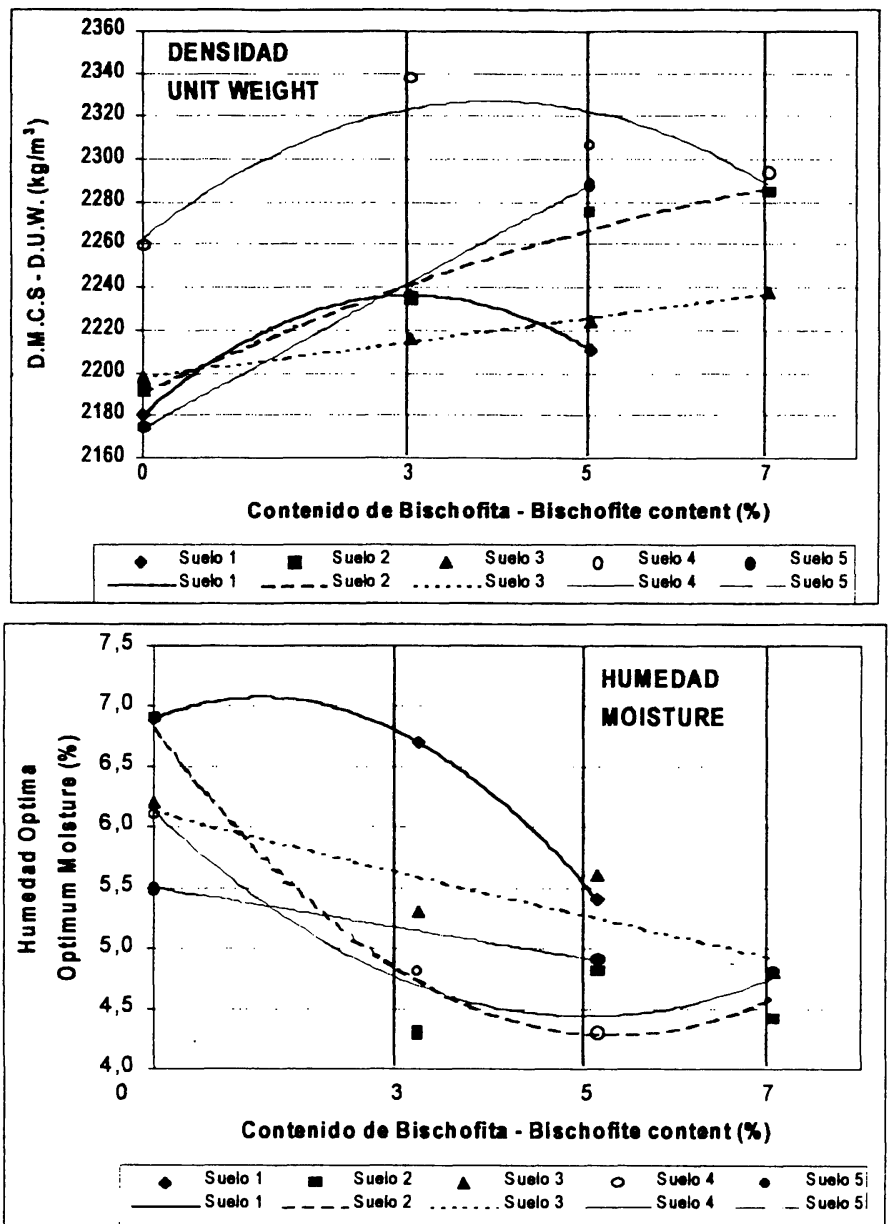

Figura 3.- Resultados del ensayo de compactación.

Figure 3.- Results of compaction test.

\section{TABLA 3/TABLE 3}

Propiedades de los suelos para el ensayo de CNC

(Soil properties for UC strength test)

\begin{tabular}{|l|c|c|c|c|c|c|c|}
\hline \multicolumn{1}{|c|}{$\begin{array}{c}\text { Tamiz } \\
\text { Sieve size }\end{array}$} & \multicolumn{7}{|c|}{$\begin{array}{c}\text { Porcentaje que pasa } \\
\text { Percent passing }\end{array}$} \\
\hline \multirow{2}{*}{ ASTM } & \multicolumn{7}{|c|}{ Suelo Soil } \\
\cline { 2 - 9 } & $\mathbf{1}$ & $\mathbf{2}$ & $\mathbf{3}$ & $\mathbf{4}$ & $\mathbf{5}$ & $\mathbf{6}$ & $\mathbf{7}$ \\
\hline N44 & 100 & 100 & 100 & 100 & 100 & 100 & 100 \\
\hline N010 & 92 & 97 & 94 & 98 & 98 & 97 & 94 \\
\hline N040 & 50 & 58 & 63 & 25 & 42 & 26 & 61 \\
\hline \multicolumn{1}{|c|}{ N200 } & 15 & 25 & 36 & 15 & 25 & 15 & 35 \\
\hline $\begin{array}{l}\text { Límite Líquido (\%) } \\
\text { Liquid Limit (\%) }\end{array}$ & - & - & - & 25 & 25 & 26 & 26 \\
\hline $\begin{array}{l}\text { Límite Plistico (\%) } \\
\text { Plastic Limit (\%) }\end{array}$ & - & - & - & 19 & 19 & 15 & 15 \\
\hline $\begin{array}{l}\text { Indice de Plasticidad } \\
\text { Plasticity Index }\end{array}$ & NP & NP & NP & 6 & 6 & 11 & 11 \\
\hline Clasificasión - Classification & A-1-b & A-2-4 & A-4 & A-1-b & A-1-b & A-2-6 & A-2-6 \\
\hline AASHTO & SM & SM & SM & SM - SC & SM - SC & SC & SC \\
\hline USCS
\end{tabular}



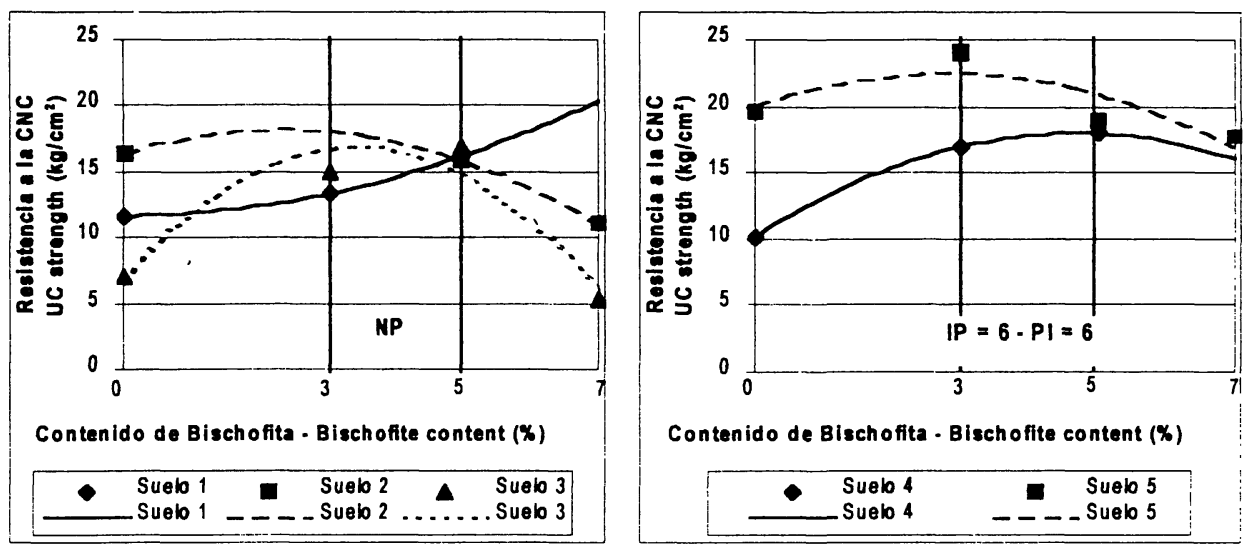

Contenido de Bisch ofita - Bisch ofite content (\%)

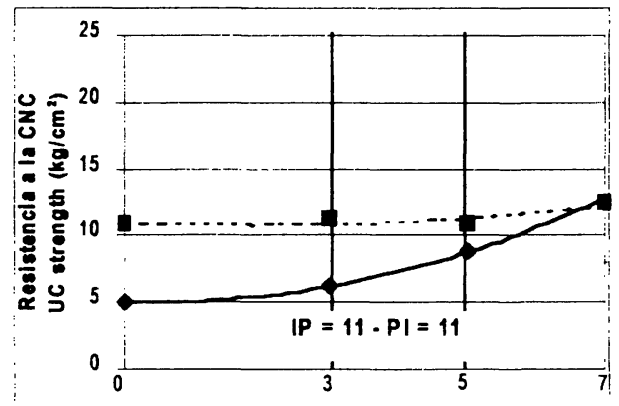

Contenido de Bisch ofita - Bisch ofite content (x)

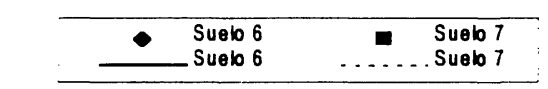

Figura 4.- Resistencia a la compresión no confinada (14 días de curado).

Figure 4.- Unconfined compression strength (14 days curing period).

Además, se observa que existe poca variabilidad en la resistencia a la CNC para las distintas dosis de Bischofita, especialmente para 3 y $5 \%$ de Bischofita.

\section{Retención de humedad}

La Figura 5 muestra el contenido de humedad de los mismos suelos utilizados en el ensayo de CNC después de un período de curado de 14 días. Se observa que suelos tratados con Bischofita presentan un mayor contenido de humedad que los suelos sin Bischofita y que el contenido de humedad es mayor mientras mayor es la dosis de Bischofita. Esto muestra la capacidad de la Bischofita de retener la humedad, incluso bajo condiciones de humedad relativa muy baja. Este hecho se debe principalmente a la menor presión de vapor de una solución de Bischofita.
It can also be observed that there is low variability in the UC strength for different Bischofite contents, especially with Bischofite contents of 3 and $5 \%$.

\section{Humidity retention}

Figure 5 shows the moisture content of the same soils used in the UC strength tests after 14 days of curing. It can be observed that soils with Bischofite have the highest moisture contents and are proportional to the Bischofite content. This shows the capacity of Bischofite to retain water, even under conditions of low relative humidity, a fact principally due to the lower vapor pressure. 


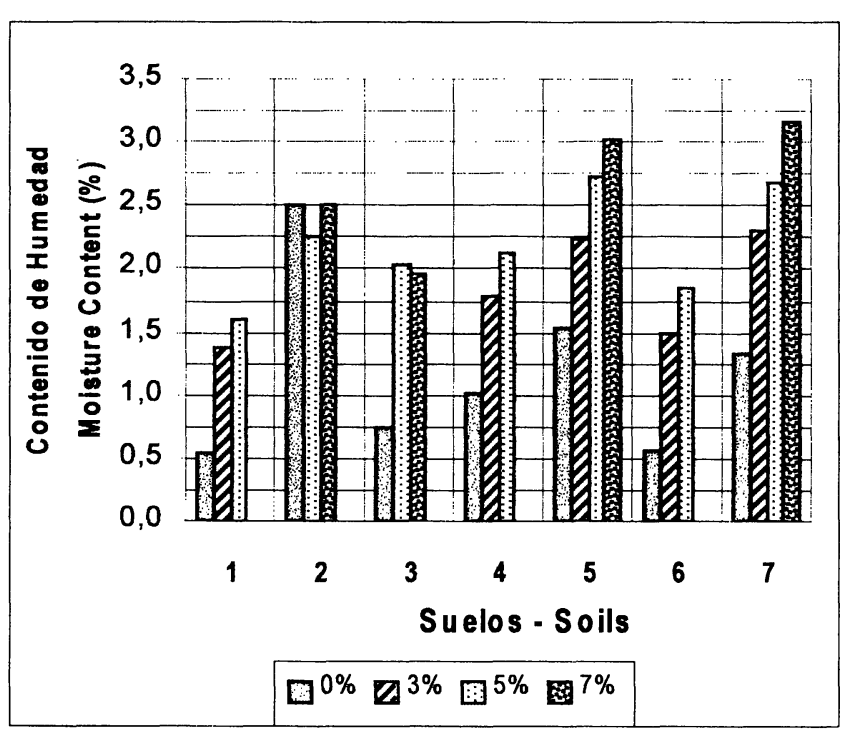

Figura 5.- Contenido de humedad de los suelos (14 días de curado).

Figure 5.- Moisture content of soils (14 days of curing).

\subsection{Investigación en terreno}

La investigación en terreno consistió en evaluar periódicamente proyectos de caminos y tramos de prueba estabilizados con Bischofita. El propósito de estas evaluaciones fue determinar el comportamiento funcional y estructural en terreno de capas de rodadura estabilizadas con Bischofita bajo distintas condiciones climáticas, utilizando diferentes tipos de suelos y dosis de Bischofita.

\section{Proyectos de caminos estabilizados con Bischofita}

\section{Descripción}

Los proyectos de caminos estabilizados con Bischofita corresponden a caminos de grava, construidos utilizando principalmente el material de la superficie de rodado existente y dosis de Bischofita cercanas al 5\%. Se estudiaron tres proyectos:

Camino Internacional San Francisco $(50 \mathrm{~km})$ : construido hace dos años, se ubica en un clima árido, donde la humedad relativa promedio es superior al $70 \%$, pero durante la tarde puede ser tan baja como $30 \%$. El volumen de tránsito es cercano a 200 veh/día, y está conformado por un alto porcentaje de vehículos pesados (superior al 35\%). La capa de rodadura está constituida por un suelo A-1 (SW-SM), y tiene un espesor de $15 \mathrm{~cm}$.

Camino Barranquilla (32 km) y Camino Puerto Viejo $(38 \mathrm{~km})$ : fueron construidos hace un año. Están

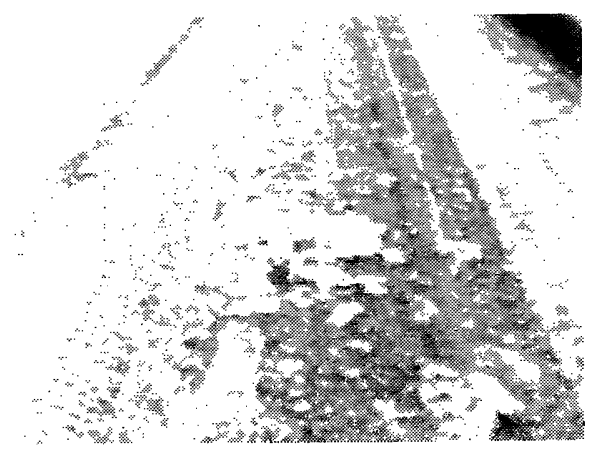

Figura 6.- Material fino suelto en suelos ar.:1llosos.

Figure 6.- Loose fine material in clay soils.

\subsection{Field study}

The field study consisted of periodic evaluation of road projects and test road sections that were stabilized with Bischofite. The objective of these evaluations was to determine the in-situ functional and structural performance of granular road surfaces stabilized with Bischofite under different climatic conditions, soils and Bischofite contents.

\section{Road projects stabilized with Bischofite}

\section{Description}

The road projects stabilized with Bischofite are gravel roads, which were rebuilt with the same material of the existing granular road surface plus 5\% of Bischofite. Three projects were studied:

San Francisco International Road $(50 \mathrm{~km})$ : built two years ago, located in an arid climate, where the average relative humidity is higher than $70 \%$, , although daytime humidity may be as low as $30 \%$. The traffic volume is close to 200 veh/day, and is conformed by a high percentage of heavy vehicles (above 35\%). Granular road surface is composed of soil $A-1$ (SW-SM), and has a thickness of $15 \mathrm{~cm}$.

Barranquilla (32 km) and Puerto Viejo (38 km) roads: built one year ago, both projects are 
ubicados en un clima árido costero, donde la humedad relativa promedio es superior al $70 \%$. El tránsito está constituido por vehículos ligeros (150 veh/día). La capa de rodadura tiene un espesor de $10 \mathrm{~cm}$, y está conformada por distintos tipos de suelos (A-1-b, A-24 y A-2-6). La velocidad de operación de los vehículos era menor a $50 \mathrm{~km} / \mathrm{h}$ en la situación original (camino no estabilizado con Bischofita).

\section{Evaluación}

El comportamiento de todos los proyectos de caminos estabilizados con Bischofita ha sido excelente, casi en toda su extensión presentan una carpeta de rodado estable, sin liberación de polvo ni formación de baches, corrugaciones y pérdida de material, presentando, además, una excelente calidad de rodadura que permite una velocidad de circulación de $100 \mathrm{~km} / \mathrm{h}$

La estabilización con Bischofita del camino Internacional San Francisco fue efectiva por más de 2 años sin ningún tipo de conservación. Después de este período, el $80 \%$ del camino se ha comportado como un camino de grava sólo estabilizado mecánicamente.

Durante 1 año, la Bischofita ha sido efectiva en los caminos de Barranquilla y Puerto Viejo. Estos, sólo presentan algunos tramos con baches y pérdida de material (menos del 10\% de la extensión total). Estos deterioros son atribuidos a la variabilidad de un proceso constructivo poco controlado (dosificación de Bischofita, homogeneización del suelo, compactación, otros).

El efecto de las lluvias (hasta $40 \mathrm{~mm}$ al año) fue evaluado. Se observó que tramos conformados por arcilla presentaron un tipo particular de deterioro: la fracción superior de la capa de rodadura, en un espesor menor a $10 \mathrm{~mm}$, se saturó con agua y el material era removido por los neumáticos de los vehículos (Figura 6). Pero, en ningún caso, las lluvias afectaron la estabilidad estructural de la capa de rodadura, sin embargo, la superficie se tornó resbaladiza. En tramos conformados por suelos no plásticos, el deterioro descrito no se manifestó, y la lluvia tampoco afectó la estabilidad estructural.

Hay que notar que los tramos deteriorados en los caminos de Barranquilla y Puerto Viejo no producen emisiones de polvo. $Y$ aunque afectan moderadamente la calidad de rodadura, la velocidad de operación segura es superior a $80 \mathrm{~km} / \mathrm{h}$. De acuerdo a la situación descrita, los autores estiman que la efectividad de la Bischofita se prolongará por 8 meses o más. located in semi-arid climates, where the average relative humidity is higher than $70 \%$. Light vehicles (150 veh/day) compose the traffic. Granular road surface presents a thickness of $10 \mathrm{~cm}$, and is composed of different soil types (A-1-b, $A-2-4$ and $A-2-6)$. Vehicle operating speed is less than $50 \mathrm{~km} / \mathrm{h}$ in the road's original condition (not stabilized with Bischofite).

\section{Evaluation}

The performance of all road projects has been excellent. In almost all their extension these roads present a stable granular road surface, without dust, potholes, corrugations and erosion. Moreover, these roads show an excellent riding quality, allowing for operating speeds of up to $100 \mathrm{~km} / \mathrm{h}$.

The stabilization with Bischofite of the San Francisco International Road was effective for more than 2 years, without any type of maintenance. After this time, $80 \%$ of the road has behaved as a gravel road only stabilized mechanically.

For one year, Bischofite has been showing positive effects on the Barranquilla and Puerto Viejo roads. These roads only present some sections with potholes and erosion (less than 10\% of their total extension). These deteriorations are attributed to the variability of a construction process with low control (Bischofite dosage, soil homogenization, compaction, among others).

The effect of precipitation was evaluated (above $40 \mathrm{~mm}$ per year). It was observed that road sections composed of clay presented a particular type of deterioration: the upper fraction of the granular road surface was saturated with water (in a thickness less than $10 \mathrm{~mm}$ ), and the material was removed by vehicles tires (Figure 6). However, in no case did precipitation affect the structural stability of the granular road surface, although the surface did become slippery. In road sections composed by non-plastic soils, neither the described deterioration was produced, nor did precipitation affect the road's structural stability.

It is important to note that deteriorated road sections in the Barranquilla and Puerto Viejo roads did not present dust emissions. Although this deterioration moderately affected the riding quality, safe vehicle operation speed is above $80 \mathrm{~km} / \mathrm{h}$. Taking into account the described situation, the authors consider that the Bischofite's effectiveness will continue for at least another 8 months. 
$\underline{\text { Tramos de prueba }}$

\section{Descripción}

Corresponden a capas de rodadura estabilizadas con Bischofita cuya extensión es de $500 \mathrm{~m}$. Además se construyeron tramos patrones (no estabilizados con Bischofita) para comparar el comportamiento funcional y estructural. Se construyeron cuatro tramos de prueba en un año: Los Choros, Ray Rock, San Pedro de Atacama y Chiu-Chiu. Dependiendo del tramo de prueba, el ancho de calzada variaba entre 6 y $7 \mathrm{~m}$, y el espesor de la capa de rodadura entre 10 y $15 \mathrm{~cm}$.

Los tramos de prueba de Los Choros y Ray Rock presentan una alta humedad relativa promedio, aunque durante la tarde ésta puede ser inferior al $40 \%$. Los tramos de San Pedro y Chiu-Chiu están localizados a gran altitud y en una zona de muy baja humedad relativa en el día y la noche.

Las principales características de cada tramo se indican en la Tabla 4.

\section{Evaluación}

La Tabla 5 presenta la evaluación de los distintos tramos de prueba estabilizados con Bischofita y tramos patrones. Esta evaluación se basa en una escala de 0 (ausencia del deterioro) a 5 (deterioro severo que causa una considerable reducción de la velocidad de circulación) para cada tipo de deterioro.

En la Tabla 5 se observa que en todos los tramos de prueba, la utilización de Bischofita permite eliminar la liberación de polvo, corrugaciones y textura gruesa, y reducir la formación de baches y pérdida de material. En cambio los tramos patrones presentan estos deterioros con distintos niveles de severidad.

En los tramos de Chiu-Chiu y San Pedro de Atacama (localizados en un clima muy seco) se produjo el agrietamiento de la superficie de rodadura del tramo de prueba (Figura 7). La causa probable del agrietamiento es la retracción del material granular debido al incremento de la tensión superficial junto a una muy baja humedad relativa prevaleciente en estos lugares. En estos tramos, aunque no existe la humedad suficiente para que la superficie de rodadura la absorba, no hay liberación de polvo, baches ni corrugaciones. Esto es consecuencia del mecanismo de cementación de partículas finas en la superficie de rodadura (por cristalización de la Bischofita).

Todos los tramos de prueba presentan una excelente calidad de rodadura que permite circular a una velocidad de $100 \mathrm{~km} / \mathrm{h}$.

\section{$\underline{\text { Test road sections }}$}

\section{Description}

These correspond to $500 \mathrm{~m}$ long granular road surfaces stabilized with Bischofite. Also, control road sections (without Bischofite) were built to compare functional and structural performance. Four test road sections were built in one year: Los Choros, Ray Rock, San Pedro de Atacama and ChiuChiu. Depending on the test road section, road width varies between 6 and $7 \mathrm{~m}$, and the thickness of the surface course between 10 and $15 \mathrm{~cm}$.

The Los Choros and Ray Rock test road sections are located in a zone with high night-time humidity, although daytime humidity can be less than $40 \%$. The San Pedro and Chiu-Chiu test road sections are located in zone of high elevation and the daytime and night-time humidity is very low.

The main characteristics of each test road section are indicated in Table 4.

\section{Evaluation}

Table 5 shows the evaluation of the test road and control road sections. They were evaluated on a scale of 0 (no deterioration) to 5 (deterioration producing a considerable reduction of vehicle operating speed) for each deterioration type.

Table 5 shows that in all test road sections the use of Bischofite eliminates dust emissions, corrugations, and coarse texture, well as reducing potholes and erosion. On the other hand, the control sections present different types of deterioration with different degrees of severity.

The test road sections of Chiu-Chiu and San Pedro de Atacama (located in a very dry climate) present cracking in the road surface (Figure 7). The probable cause of cracking is granular material shrinkage caused by the increase of surface tension and low humidity in the zone. Even though these areas do not present much humidity to be absorbed by the road surface, there are no dust emissions, potholes or corrugations. This is a result of the cementation mechanism of fine particles in road surfaces (by Bischofite crystallization).

All test road sections show excellent riding quality allowing a vehicle operating speed of $100 \mathrm{~km} / \mathrm{h}$. 


\section{TABLA 4/TABLE 4}

Características de los tramos de prueba

(Characteristics of the test road sections)

\begin{tabular}{|c|c|c|c|c|}
\hline & \multirow{2}{*}{\multicolumn{4}{|c|}{ Tramo de prueba/Test road section }} \\
\hline & & & & \\
\hline & Los Choros & Ray Rock & San Pedro & Chiu-Chiu \\
\hline ASTM & \multicolumn{4}{|c|}{ Porcentaje que pasa/Percent passing } \\
\hline $2 "$ & 100 & & & \\
\hline $11 / 2^{\prime \prime}$ & 98 & 100 & 100 & 100 \\
\hline 1" & 82 & 99 & 94 & 99 \\
\hline $3 / 4^{\prime \prime}$ & 74 & 97 & 90 & 98 \\
\hline $3 / 8 "$ & 56 & 91 & 78 & 91 \\
\hline $\mathrm{N}^{\circ} 4$ & 46 & 77 & 58 & 81 \\
\hline $\mathrm{N}^{\circ} 10$ & 35 & 62 & 51 & 71 \\
\hline $\mathrm{N}^{\circ} 40$ & 21 & 41 & 37 & 49 \\
\hline No200 & 9 & 14 & 28 & 18 \\
\hline LímiteLíquido/Liquid Limit & 27 & & 27 & \\
\hline Límite Plástico/Plastic Limit & 14 & & 13 & \\
\hline Indice de Plasticidad/Plasticity Index & 13 & NP & 14 & NP \\
\hline \multicolumn{5}{|l|}{ Clasificación/Classification } \\
\hline AASHTO & $A-2-6$ & A-1-b & A-2-6 & A-1-b \\
\hline USCS & GW - GC & SM & $\mathrm{GC}$ & SM \\
\hline $\begin{array}{l}\text { Contenido Bischofita (\%) } \\
\text { Bischofite content (\%) }\end{array}$ & 4,5 & 4,5 & $2,0 / 3,3$ & 4,5 \\
\hline
\end{tabular}

\begin{tabular}{|l|c|c|c|c|}
\hline Características del tránsito/Characteristic of traffic \\
\hline $\begin{array}{l}\text { Volumen (veh/día)/Volume (veh/día) } \\
\text { Tipo }\end{array}$ & $\begin{array}{c}<50 />150^{(1)} \\
\text { Ligero }\end{array}$ & $\begin{array}{c}>250 \\
\text { Ligero/Pesado }\end{array}$ & $\begin{array}{c}45 \\
\text { Ligero }\end{array}$ & $\begin{array}{c}80 \\
\text { Ligero }\end{array}$ \\
\hline Type & Light & Light/Heavy & Light & Light \\
\hline
\end{tabular}

\begin{tabular}{|l|c|c|c|c|}
\hline Clima/Weather ${ }^{(2)}$ & $\begin{array}{c}\text { Semi-árido } \\
\text { Semi-arid }\end{array}$ & $\begin{array}{c}\text { Árido costero } \\
\text { Arid-marine }\end{array}$ & $\begin{array}{c}\text { Árido } \\
\text { Arid }\end{array}$ & $\begin{array}{c}\text { Árido } \\
\text { Arid }\end{array}$ \\
\hline $\begin{array}{l}\text { Tipo } \\
\text { Type }\end{array}$ & 103,4 & 4,2 & 3,3 & 0,0 \\
\hline $\begin{array}{l}\text { Lluvia/Rain (mm) } \\
\text { Temperatura Promedio }\left({ }^{\circ} \mathrm{C}\right)\end{array}$ & 13,6 & 15,0 & $10,0^{(3)}$ & $10,4^{(3)}$ \\
\hline $\begin{array}{l}\text { Average Temperature }\left({ }^{\circ} \mathrm{C}\right) \\
\text { Average Relative Humidity (\%) }\end{array}$ & $83^{(4)}$ & $78^{(4)}$ & 25 & 23 \\
\hline
\end{tabular}

\section{NOTASNOTES:}

(1) Flujo vehicular: 150 veh/dia Octubre-Marzo. 50 veh/dia el resto del año

Votume of vehicles: 150 veh/day October-March. 50 veh/day the rest of year

(2) La lluvia, temperatura promedio y humedad relativa promedio corresponden al periodo entre la fecha de construcción y la evaluación final

Rain, average temperature and average relative humidity correspond to time between the construction date and the final evaluation date

(3) Variación de temperatura entre el dia y la noche es cercana a $20^{\circ} \mathrm{C}$ Variation of temperature between day and night is near to $20^{\circ} \mathrm{C}$

(4) En verano, humedad relativa desciende a menos de $40 \%$ durante la tarde In summer, relative humidity descends to less than $40 \%$ during the afternoon 
TABLA 5/TABLE 5

Evaluación de los tramos de prueba y tramo patrón

(Evaluation of test and control road sections)

\begin{tabular}{|c|c|c|c|c|c|c|c|c|}
\hline & & & \multicolumn{5}{|c|}{ Tipo de deterioro/ Type of deterioration (1) } \\
\hline & & \multicolumn{2}{|c|}{$\begin{array}{c}\text { Tramo } \\
\text { Road Section }\end{array}$} & $\begin{array}{l}\text { Baches } \\
\text { Potholes }\end{array}$ & $\begin{array}{c}\text { Calaminas } \\
\text { Corrugations }\end{array}$ & $\begin{array}{l}\text { Material suelto } \\
\text { Loose material }\end{array}$ & $\begin{array}{c}\text { Polvo } \\
\text { Dust }\end{array}$ & $\begin{array}{l}\text { Textura gruesa } \\
\text { Coarse Texture }\end{array}$ \\
\hline \multirow{5}{*}{ : } & \multirow{5}{*}{ 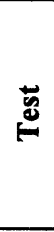 } & Los Choros & $\cdots$ & 2 & 0 & 0 & 0 & 0 \\
\hline & & Ray Rock & $\ldots$ & 1 & 0 & 0 & 0 & 0 \\
\hline & & San Pedro & $1(2)$ & 2 & 0 & 1 & 0 & 0 \\
\hline & & de Atacama & $2(3)$ & 1 & 0 & 0 & 0 & 0 \\
\hline & & Chiu-Chiu & --- & 1 & 0 & 0 & 0 & 0 \\
\hline \multirow{4}{*}{ 点 } & \multirow{4}{*}{ 它 } & Los Choros & (4) & 3 & 1 & 3 & 3 & 2 \\
\hline & & Ray Rock & --- & - & $-\cdots$ & -- & --- & --- \\
\hline & & Sn. Pedro de At. & -- & 2 & 0 & 1 & 0 & 0 \\
\hline & & Chiu-Chiu & --- & 3 & 3 & 3 & 4 & 2 \\
\hline
\end{tabular}

\section{NOTASINOTES:}

(1) Período en servicio de cada tramo antes de la evaluación / Time in senvice of each road section before evaluation Los Choros: 12 meses / months - Ray Rock: 9 meses / months - San Pedro de Atacama: 6 meses / months - Chiu-Chiu: 5 meses / months

(2) Dosis de Bischofita igual a $2 \%$ - Bischofite content equal to $2 \%$

(3) Dosis de Bischofita igual a 3,3 \% - Bischofite content equal to 3,3\%

(4) Tramo patrón con imprimación (MC-30) - Control road section with prime coa. (MC-30)

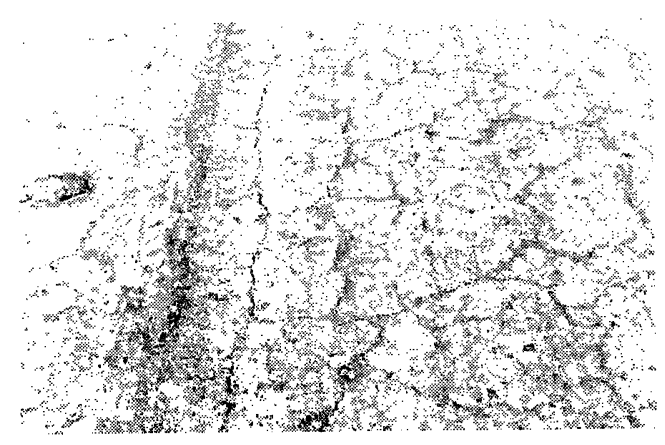

Figura 7.- Agrietamiento de la superficie de rodadura.

Figure 7.- Cracking of road surface.
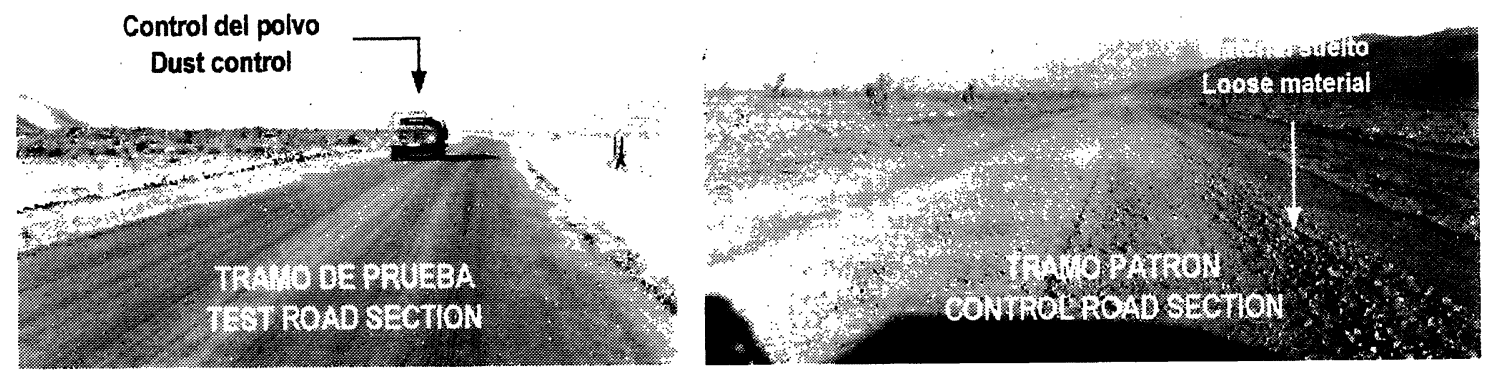

Figura 8.- Estado del tramo de prueba y tramo patrón.

Figure 8.- Condition of the test road and control road sections. 
Como ejemplo, la Figura 8 muestra el tramo de prueba y patrón de Los Choros después de 1 año en servicio, en general la situación es similar para el resto de los tramos de prueba y proyectos de caminos estabilizados.

De acuerdo a la situación de los tramos de prueba al momento de la evaluación, los autores esperan que la efectividad de la Bischofita se prolongará, al menos, por un año más.

\subsection{Otros resultados}

Como consecuencia de las investigaciones de terreno y laboratorio se obtuvieron otros resultados importantes, los principales son:

\section{Dosis de Bischofita}

La dosis de Bischofita depende de las propiedades plásticas y contenido de finos del suelo. De acuerdo a los ensayos de laboratorio de resistencia a la CNC, la dosis óptima de Bischofita para la mayoría de los suelos estudiados debería ser 3 a $5 \%$. Por otro lado, los resultados de terreno muestran una tendencia a que suelos no plásticos se comportan bien con dosis de Bischofita cercanas al 5\%, independiente del porcentaje de finos del suelo.

Los suelos más plásticos se mantienen mejor con dosis de Bischofita cercanas al 3\%. En éstos se aprecia una tendencia a que con mayor contenido de finos se requieren dosis más bajas de Bischofita. Este hecho es debido a que suelos más plásticos poseen la cohesión necesaria para mantener la capa de rodado estable en climas áridos. En este caso, el uso de la Bischofita permite mantener la superficie húmeda, de tal manera que se reduce la tasa de deterioro del camino.

No se encontró una relación clara entre porcentaje de finos y dosis de Bischofita para suelos plásticos, por ello, la Tabla 6 muestra las dosis de Bischofita recomendadas solamente de acuerdo al índice de plasticidad del suelo.

\section{Banda granulométrica}

De acuerdo a las especificaciones existentes para materiales granulares que conforman capas de rodadura, y a los resultados de la presente investigación, se estableció la banda granulométrica recomendada para ser utilizada en capas de rodadura granulares estabilizadas con Bischofita, la cual se muestra en la Tabla 7.

El límite líquido máximo recomendado es $35 \%$. El índice de plasticidad máximo igual a 15 para climas muy áridos, y 6 para climas húmedos.
As an example, Figure 8 shows the test road and control road section of Los Choros after one year in service. In general, the situation is similar for the remaining test road sections and road projects stabilized with Bischofite.

As a result of the condition of the test road sections at the time of evaluation, the authors consider that the effectiveness of Bischofite will continue for at least another year.

\subsection{Other results}

As a consequence of the field and laboratory investigations other important results were obtained, the principal ones being:

\section{Bischofite content}

Bischofite content depends upon the plastic properties and fine particle content of the soil. According to UC. strength test results, the optimum Bischofite content varies between 3 and $5 \%$. On the other hand, the field results show that the best results in non-plastic soils were obtained with a Bischofite content of 5\%, regardless of the fine particle content of the soil.

In plastic soils, the best results were obtained with a Bischofite content of $3 \%$. It is considered that soils with higher fine particle contents require a lower Bischofite content. This can be explained by the fact that plastic soils have sufficient cohesion to maintain road stability in arid zones. In this case, the use of Bischofite allows to maintain a humid road surface, reducing the road's rate deterioration.

The relationship between the percentage of fine particles and Bischofite contents for plastic soils was not found. For that reason, Table 6 shows only the recommended Bischofite content according to the soil's plasticity index.

\section{Gradation requirements}

Based on existing standard specifications for granular soils and the results of this study, the gradation recommended for granular road surfaces stabilized with Bischofite is shown in Table 7.

The maximum liquid limit recommended is $35 \%$. The maximum plasticity index is 6 (for humid zones) and 15 (for arid zones). The construction of 
TABLA 7/TABLE 7

Granulometría recomendada para superficies granulares de rodado

(Gradation requirements for granular road surfaces)

TABLA 6/TABLE 6

Dosis de Bischofita

(Bischofite contents)

\begin{tabular}{|c|c|}
\hline $\begin{array}{c}\text { IP } \\
\text { PI }\end{array}$ & $\begin{array}{c}\text { Dosis de Bischofita (\%) } \\
\text { Bischofite content (\%) }\end{array}$ \\
\hline NP - 3 & $4-5$ \\
\hline $4-8$ & $3-5$ \\
\hline $9-15$ & $3-4$ \\
\hline
\end{tabular}

\begin{tabular}{|c|c|}
\hline $\begin{array}{c}\text { Tamiz (mm) } \\
\text { Sieve size (mm) }\end{array}$ & $\begin{array}{c}\text { Porcentaje que pasa } \\
\text { Percent passing }\end{array}$ \\
\hline 50,0 & 100 \\
\hline 25,0 & $80-100$ \\
\hline 10,0 & $50-100$ \\
\hline 4,75 & $35-85$ \\
\hline 2,00 & $25-70$ \\
\hline 0,425 & $15-45$ \\
\hline 0,080 & $8-25$ \\
\hline
\end{tabular}

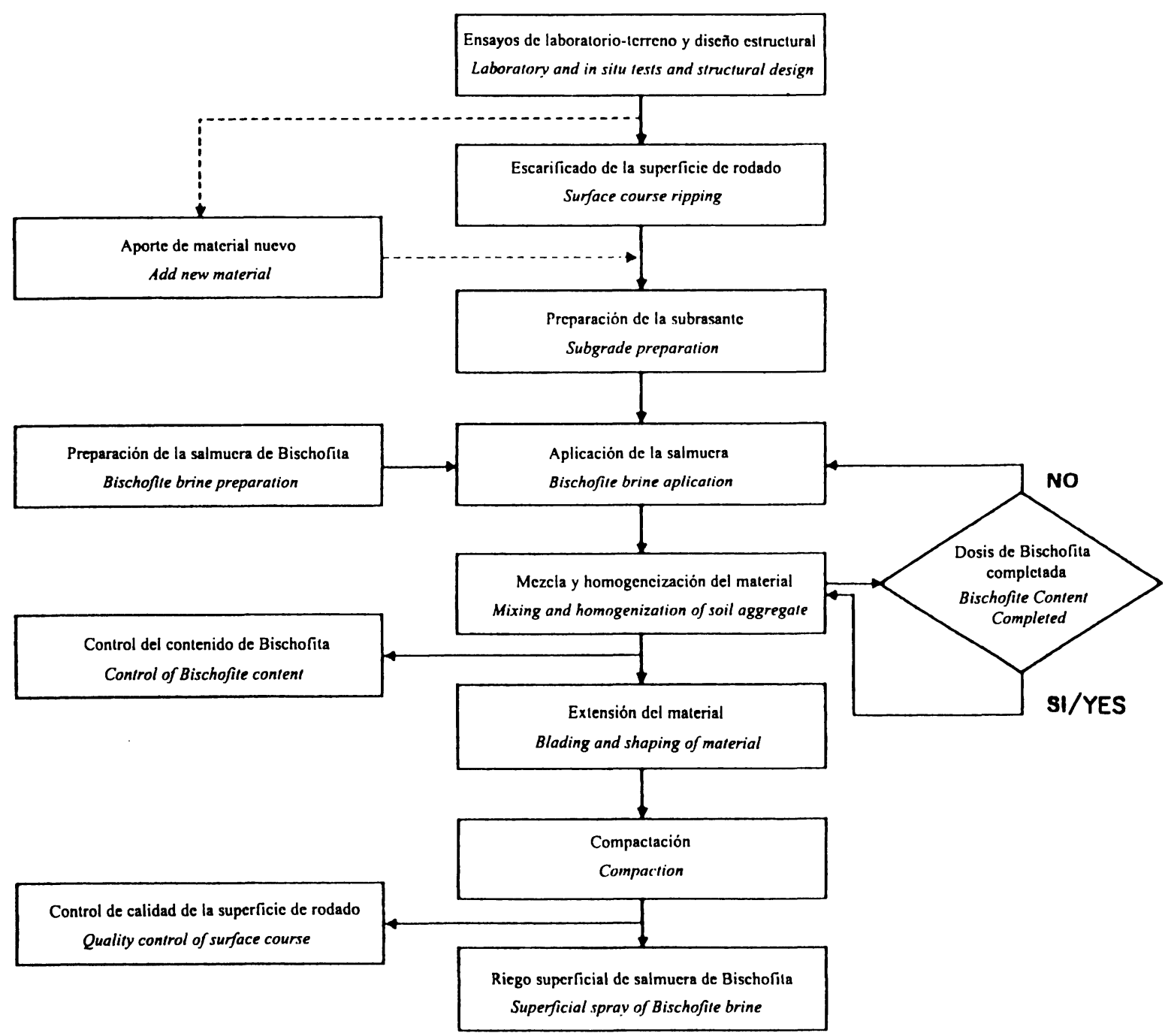

Figura 9.- Diagrama del proceso constructivo para capas de rodadura estabilizada con Bischofita.

Figure 9.- Diagram of the construction process for granular road surface stabilized with Bischofite. 


\section{Proceso Constructivo}

El proceso de construcción de una capa de rodadura utilizando Bischofita es muy similar al proceso tradicional de construcción de caminos de grava, difiere principalmente en que es necesario preparar la salmuera de Bischofita, y aplicar ésta en reemplazo del agua de compactación. Además, experimentalmente se observó que la aplicación de un riego de salmuera de Bischofita sobre la superficie de la capa compactada, seguido de un ciclo de compactación con un rodillo estático, mejora la textura superficial del camino (más cerrada y homogénea).

El proceso constructivo se esquematiza en la Figura 9.

\section{Medio Ambiente}

En la actualidad se están realizando experiencias para determinar el grado de lixiviación que pueda ocurrir debido a la lluvia, y de este modo poder evaluar el efecto de la Bischofita sobre la flora y fuentes de agua.

Hay que notar, que el cloruro de magnesio es considerado ambientalmente seguro y ha sido aprobado por la Agencia de Protección Ambiental y Servicio Forestal de Estados Unidos (6).

\section{CONCLUSIONES}

Aunque se han realizados estudios para evaluar la efectividad del cloruro de magnesio (o Bischofita) como supresor temporal de polvo, no hay investigaciones relacionadas a su uso como estabilizador de caminos no pavimentados. El artículo presenta los resultados de la investigación en terreno y laboratorio para evaluar la efectividad de la Bischofita como estabilizador químico de capas granulares de rodadura en caminos de bajo volumen de tránsito ( $<250 \mathrm{veh} /$ día). Las principales conclusiones son:

1. Los resultados de la investigación en terreno muestran que la Bischofita es un efectivo estabilizador de capas granulares de rodadura ubicadas en climas áridos. Caminos estabilizados con Bischofita no presentan liberación de polvo y corrugaciones, reduciéndose la formación de baches y pérdida de material. Además, los caminos estabilizados con Bischofita presentan una excelente calidad de rodadura cercana a la de caminos pavimentados.

2. La efectividad de la Bischofita es superior a dos años sin ningún tipo de conservación. Como consecuencia se pueden obtener importantes

\section{Construction}

The construction of granular road surfaces stabilized with Bischofite is similar to the traditional construction process of gravel roads. The main differences are the preparation and application of Bischofite brine. In addition, it was observed experimentally that applying a light spray of Bischofite brine on an already compacted granular surface (plus a compaction cycle with a static roller) improves the road's surface texture (more closed and homogeneous).

The construction process is shown in Figure 9.

\section{Environmental}

At the present time, experiments are being carried out to determine the degree of leaching due to precipitation, in order to be able to evaluate the effect of Bischofite on flora and water sources.

It is important to note that magnesium chloride is environmentally safe and has been approved by the US Environmental Protection Agency and the US Forest Service (6).

\section{CONCLUSIONS}

Although studies have been conducted to evaluate the effectiveness of magnesium chloride (or Bischofite) as an unpaved road dust suppressant, there are no studies related to its effectiveness as a chemical stabilizer of granular road surfaces. This paper presents the results of the field and laboratory investigations conducted to evaluate the performance of Bischofite as a chemical stabilizer of granular road surfaces for low traffic volume roads (less than 250 veh/day). The main conclusions are:

1. The field results show that Bischofite is an effective stabilizer of granular road surfaces in arid climates. Roads stabilized with Bischofite remain dust and corrugations free, as well as showing reductions in potholes and erosion. Moreover, roads stabilized with Bischofite present excellent riding quality approaching that of paved roads.

\section{The period of Bischofite's effectiveness is more} than two years without any type of maintenance. Therefore, important savings are obtained in 
ahorros por conceptos de costos de conservación del camino y costos de operación de los vehículos, además de diversos beneficios sociales.

3. La lluvia produce dos problemas en tramos conformados por arcilla: desprendimiento del material fino saturado y superficie resbaladiza.

4. En climas muy secos, la superficie de rodadura no absorbe humedad del ambiente, en este caso, el mecanismo de estabilización que actúa es la cementación de partículas finas de la superficie.

5. La Bischofita produce un importante mejoramiento de las propiedades de compactabilidad de los suelos, debido a un incremento de las densidades secas de compactación y una reducción del contenido de humedad óptimo.

6. Las dosis de Bischofita recomendada varía entre 3 y $5 \%$ dependiendo principalmente de las propiedades plásticas del suelo.

7. Se estudiaron suelos con un rango amplio de contenido de finos, entre 8 y $35 \%$, y los resultados no permiten indicar que alguno de estos suelos no sea apto para ser estabilizado con Bischofita, sin embargo, se recomienda limitar el contenido de finos a un máximo de $25 \%$.

8. La calidad final y desempeño del camino estabilizado con Bischofita dependen principalmente de la calidad de la construcción, en particular, de la adecuada homogeneización del suelo con la Bischofita y la terminación superficial de la capa de rodadura.

9. De acuerdo a estos resultados, los autores recomiendan el uso de Bischofita para la estabilización de capas de rodadura de caminos no pavimentados ubicados en climas áridos y semiáridos. Se requiere realizar otros estudios para evaluar la efectividad en climas húmedos, donde el nivel de lluvia sea mayor. terms of road maintenance costs and vehicle operation costs, in addition to diverse social benefits.

3. Precipitation produces two problems in road sections composed of clay: loosening of saturated fine material and slippery road surfaces.

4. In very arid climates, road surfaces absorb no air humidity, in this case, the active stabilization mechanism is the cementation of fine surface particles.

5. Bischofite produces significant improvement in the compaction properties of soils, increasing the soil's dry unit weight and decreasing its optimum moisture content.

6. Depending on the soil's plastic properties, the recommended Bischofite content is between 3 and $5 \%$

7. Several soils were studied with fine particle contents between 8 and 35\%, results indicating that all soils are appropriate for stabilization with Bischofite, although the maximum fine particle content recommended is $25 \%$.

8. The finished road's quality and performance of $a$ granular road surface stabilized with Bischofite depends mainly upon the construction quality, specifically, good homogenization between Bischofite and the soil, and the finished road's surface texture

9. According to research results, the authors recommend the use of Bischofite for the stabilization of granular surfaces on unpaved roads located in arid and semi-arid zones. It is necessary to carry out further studies to evaluate the effectiveness of Bischofite in humid zones with higher precipitation levels.

\section{REFERENCIAS}

(1)Foley, G., Cropley, S. \& Giummarra, G. Road Dust Control Techniques: Evaluation ofChemical Dust Suppressant' Perfomance. Australian Road Research Board Special Report N 54, Vermount South, 1996.

(2) Bolander, P. Chemical Additives for Dust Control. Transportation Research Record N 1.589, pp. 42-49, Washington DC, 1997.

(3) Kézdi, A. Stabilized Earth Roads. Elsevier Scientific Publishing Company, New York, 1979.

(4) Juárez, E. y Rico, A. Fundamentos de la Mecánica de Suelos - Tomo 1. Editorial Limusa, México, 1978.

(5)Singh, G. \&Das, B. Soil Stabilization with Sodium Chloride. Transportation Research Record N 1.673,pp. 46-55, Washington DC, 1999.

(6) Houssa, C. (unpublished) Magnesia and Magnesium Compounds: A Global Producers and market Review. Industrial Minerals Research, pp. 152, London, 2000. 